Article

\title{
Characteristics of Yield and Harvest Index, and Evaluation of Balanced Nutrient Uptake of Soybean in Northeast China
}

\author{
Wenting Jiang ${ }^{1}$, Xiaohu Liu ${ }^{2, *}$, Xiukang Wang ${ }^{1, *(\mathbb{D})}$ and Yuan Yin ${ }^{2}$ \\ 1 College of Life Science, Yan'an University, Yan'an 716000, China; jiangwenting@yau.edu.cn \\ 2 College of Land and Environmental, Shenyang Agriculture University, Shenyang 110866, China; \\ yinyuanyuan1111@163.com \\ * Correspondence: liuxiaohu@syau.edu.cn (X.L.); wangxiukang@yau.edu.cn (X.W.)
}

Received: 15 May 2019; Accepted: 11 June 2019; Published: 13 June 2019

\begin{abstract}
The balance between fertilizer application and plant nutrient demand is essential for ensuring agricultural production because it is effective to prevent nutrient deficiency and excess, especially for soybean. This study used data from 29 sites of field experiments carried out in the soybean planting area of Liaoning province, China in 2011 to 2013. We (i) study the characteristics of yield, nutrient concentration, and harvest index to (ii) valuate the balanced nutrient uptake at different potential yield levels for soybean. The grain yield ranged from 804 to $4484 \mathrm{~kg} / \mathrm{ha}$, and average N, P, and K concentrations in grains were $45.7,5.0$, and $10.1 \mathrm{~g} / \mathrm{kg}$, respectively, while those in straw were 14.1, 1.8, and $6.7 \mathrm{~g} / \mathrm{kg}$, respectively. Average harvest index values of $\mathrm{N}, \mathrm{P}$, and $\mathrm{K}$ were 0.69 , 0.65 , and $0.52 \mathrm{~kg} / \mathrm{kg}$, respectively, while approximately $69 \% \mathrm{~N}$ and $65 \% \mathrm{P}$ of the plant were stored in soybean grain, and $48 \% \mathrm{~K}$ was stored in straw. The two boundary lines of the QUEFTS (quantitative evaluation of the fertility of tropical soils) model were $\mathrm{aN}=10.5, \mathrm{dN}=20.6, \mathrm{aP}=65.6, \mathrm{dP}=289.6$, $\mathrm{aK}=30.4$, and $\mathrm{dK}=162.7$ as model parameters. The QUEFTS model estimated the balanced nutrient uptake with yield targets increased following a linear-parabolic-plateau curve. A continual linear increase in grain yield with $65.5 \mathrm{~kg} \mathrm{~N}, 7.0 \mathrm{~kg} \mathrm{P}$, and $13.9 \mathrm{~kg} \mathrm{~K}$ was required to produce $1000 \mathrm{~kg}$ grain, until the yield target reached approximately $60-70 \%$ of the potential yield, and the corresponding ratio of $\mathrm{N}, \mathrm{P}$, and $\mathrm{K}$ was 9.35:1:1.8. Results could be used to estimate balanced nutrient uptake to prevent excessive fertilizer being applied and reduce environment risk for ensuring sustainable agricultural development.
\end{abstract}

Keywords: soybean; nutrient uptake; yield; internal efficiencies; harvest index

\section{Introduction}

As the population growth continue to increase and arable land resources decrease, agriculture faces great challenges [1]. Driven by the need for diet, feed, fiber, fuel, and diet diversification, demands for soybean are growing substantially in the world [2,3]. Soybean (Glycine max (L.) Merrill) is one of the most important dual-purpose crops in China, having multiple uses as a kind of vegetable oil and high-protein crop used for human consumption [4,5]. Because of this, soybean is grown around the world, and the global planting area has remained stable or increased in some areas in recent years [6]. China is one of main soybean producing countries in the world, approaching an average yield of $1.83 \mathrm{t} /$ ha in 1999 , which decreased to $1.76 \mathrm{t} /$ ha in 2005 , mainly due to poor nutrient management and lagging technological use. Application of sufficient fertilizer to meet crop demand is essential to improving production capacity, especially in yield potential. To pursue higher yield and greater economic benefit, farmers often input excessive fertilizer or apply the same nutrients over the 
entire field, ignoring crop nutrient demands $[7,8]$. This is associated with negative impacts on yields and the environment, such as a large amount of fertilizer residual in the soil, water pollution, and environmental risk $[9,10]$.

Exploring better nutrient management is one of the key factors that guide stabilizing soybean production. The application of sufficient nutrients for crop performance is critical for the growing demand for diversified diets in the nation's rapidly expanding population [11]. Obviously, nutrient management still faces the main challenge of crop growth uptake with yield variability, as well as differences in soil nutrient supply. Therefore, knowledge of balanced nutrient uptake is required to tailor nutrient management strategies to the specific regions. In the past, most nutrient practice usually ignored the interaction of plant nutrients relationships and only used limited data dealing with a single nutrient, which made for misleading fertilization [12].

Simulation models could provide a basis method for management and play a more dominant role in evaluating crop nutrient requirements. The QUEFTS model, is a linear-parabolic-plateau model that was originally used by Jassen et al. [13], which is quantitated forecasts of yields modeled on unfertilized tropical soils. The original QUEFTS model was modified by Smaling and Janssen [14], who used it to estimate nutrients requirements for a yield target, and to determine the fertilizer. It differs from other models by taking into account relationships of three nutrient elements $(\mathrm{N}, \mathrm{P}$, and $\mathrm{K}$ ), and these practical aspects are combined with field experiment [15]. The QUEFTS model as an effective tool for quantitating nutrient balances with optimal fertilizer management. The QUEFTS model is a practical approach that has been widely and successfully implemented in diverse crops, such as rice [15,16], maize [12], oilseed rape [17], and wheat [18,19]. Recently, a study on the balanced nutrient uptake of soybean applied by the QUEFTS model in China was published by Yang et al. [5]; the studies considered large experimental regions. However, the nutrient balance, nutrients applied, or output in each province of China is essential for field management [20]. Thus, the objectives of this study were to: (1) determine the boundary lines of N, P, and $\mathrm{K}$ in the relationships between grain yield and nutrient uptake for soybean; (2) evaluated the balanced nutrient uptake for yield targets.

\section{Materials and Methods}

\subsection{Database Source and Study Sites}

The data used in this study were collected from 29 experimental sites, conducted by the soil testing and fertilization project in Liaoning province in China from 2011 to 2013. Field experiment sites were located in the main soybean production region of Liaoning Province $\left(38^{\circ} 43^{\prime} \mathrm{N}-43^{\circ} 26^{\prime} \mathrm{N}\right.$, $\left.118^{\circ} 53^{\prime} \mathrm{E}-125^{\circ} 46^{\prime} \mathrm{E}\right)$, Northeast China (Figure 1). The soil was brown soil, which had the following properties (the mean concentration) at the start of the experiment: the average of $\mathrm{pH}$ was 6.7, soil organic matter was $16.7 \mathrm{~g} / \mathrm{kg}$, total $\mathrm{N}$ was $0.86 \mathrm{~g} / \mathrm{kg}$, Olsen-P was $17.8 \mathrm{mg} / \mathrm{kg}$, and available K was $102.4 \mathrm{~g} / \mathrm{kg}$. The average of silt content (50-2000 mm) was $18 \%$, with a bulk density of $1.19 \mathrm{~g} / \mathrm{cm}^{3}$.

The area has a temperate humid and semi-humid monsoon climate, with a hot, rainy season. There are distinct seasonal differences in air temperature, precipitation, wind, and meteorological events in Liaoning Province. A soybean planting scheme is sown in May and then harvested in September. During the soybean planting period, the average monthly rainfall and temperature were $98.2 \mathrm{~mm}$ and $21.4^{\circ} \mathrm{C}$, respectively. The average monthly sunshine duration was $228.3 \mathrm{~h}$. 


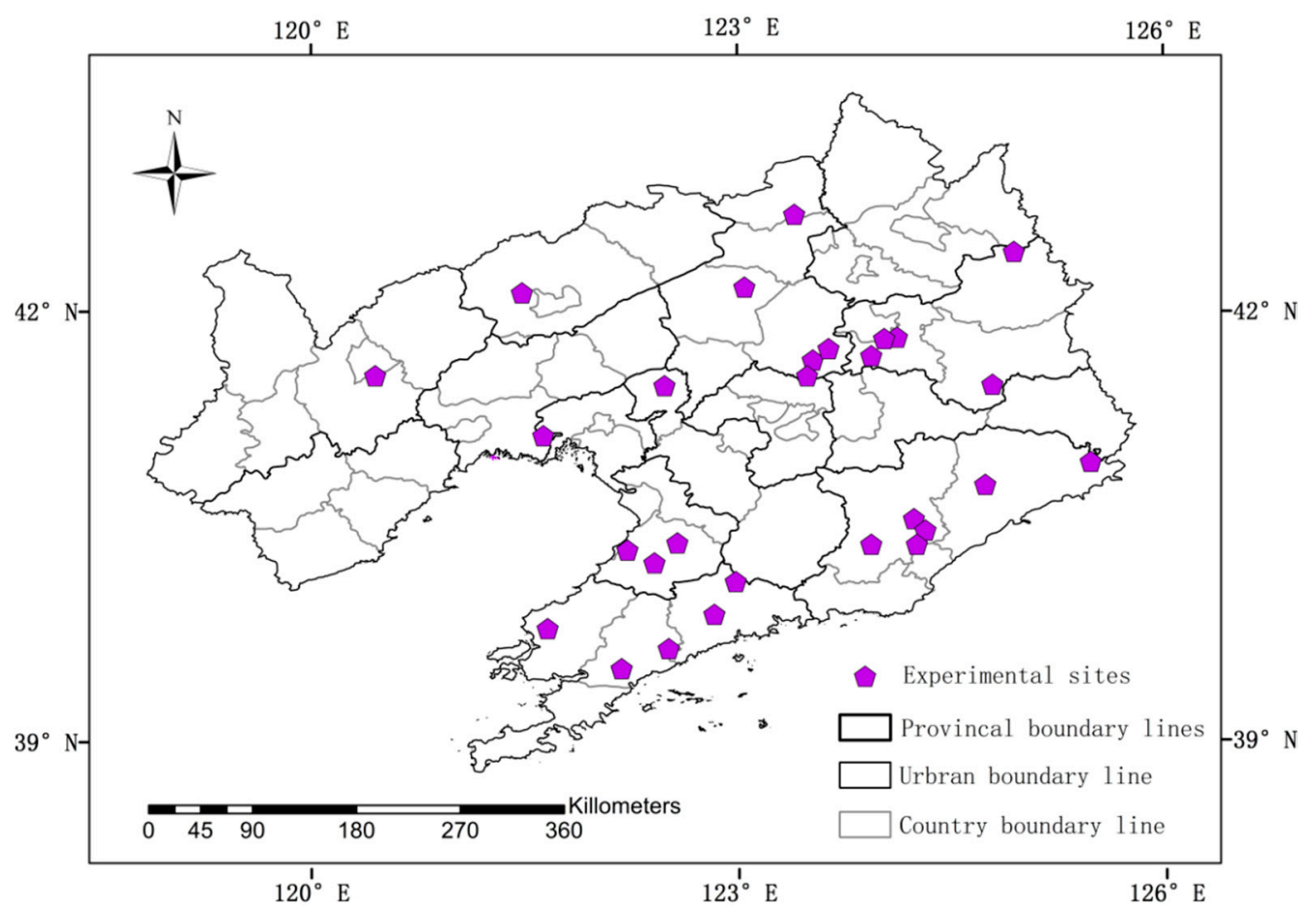

Figure 1. Location of distribution of 29 experimental sites for soybean in Liaoning province of China.

\subsection{Field Experiment Treatment and Management}

Field experiments were arranged in a randomized complete block design with three replicates of four treatments: without $\mathrm{N}$ fertilization with $0 \mathrm{~kg} \mathrm{~N} / \mathrm{ha}$, while $\mathrm{P}$ and $\mathrm{K}$ fertilizer were added in soybean growing season (N0); without $\mathrm{P}$ fertilization with $0 \mathrm{~kg} \mathrm{P}_{2} \mathrm{O}_{5} /$ ha, while $\mathrm{N}$ and $\mathrm{P}$ fertilizer were added in soybean growing season (P0); without $\mathrm{K}$ fertilization with $0 \mathrm{~kg} \mathrm{~K}{ }_{2} \mathrm{O} / \mathrm{ha}$, while $\mathrm{N}$ and P were added in soybean growing season (K0), and recommend fertilization treatment (NPK), which is based on local optimal management practice, climate, and soil. In four treatments, $\mathrm{N}$ fertilizers (excluding N0) were applied at a dose of 39-73.5 kg N/ha (urea, $46 \% \mathrm{~N}$ ), P fertilizer (excluding P0) were applied at a dose of $45-81 \mathrm{~kg} \mathrm{P}_{2} \mathrm{O}_{5} / \mathrm{ha}$ (calcium superphosphate, $12 \% \mathrm{P}_{2} \mathrm{O}$ ), and $\mathrm{K}$ fertilizer (excluding $\mathrm{K} 0$ ) were dosed with $12-75 \mathrm{~kg} \mathrm{~K}_{2} \mathrm{O} /$ ha (potassium chloride, $60 \% \mathrm{~K}_{2} \mathrm{O}$ ), respectively. Field experiments were a completely randomized block design with three replications. Field management practices, such as weed, pests, and disease were controlled by weeding, fungicide, and spraying pesticide, consistent with local farmers. Tiefeng No. 29, Shennong No. 8 and Kaiyu No. 8175 were used as common varieties.

\subsection{Sampling and Measuring}

When the soybean was harvested, the above ground plants were divided into seed and straw (including stems and leaves) to measure N, P, and K concentration. The samples were oven dried at $80^{\circ} \mathrm{C}$ for $30 \mathrm{~min}$ and at $60^{\circ} \mathrm{C}$ for $48 \mathrm{~h}$ and weighted. The dried samples were grinded and digested separately with $\mathrm{H}_{2} \mathrm{SO}_{4}-\mathrm{H}_{2} \mathrm{O}_{2}$. The concentration of $\mathrm{N}, \mathrm{P}$, and $\mathrm{K}$ were measured using Kjeldahl method, vanadium molybdate yellow colorimetric method, and flame spectrophotometer method, respectively.

\subsection{Using the QUEFTS Model Analysis}

The original purpose of the QUEFTS model was to estimate a quantitative prediction of maize yield on unfertilized tropical soils [13], however, it has since been adjusted for use with other areas or soil types. Witt et al. [15] further modified the model and used it to estimate the balanced N, P, and K uptake requirements. The advantage of the QUEFTS model is that it takes into account the relationship between nitrogen, phosphorus, and potassium, rather than the demand for one nutrient element alone. 
In this research, we simulated the balanced nutrient uptake for yield potential following Ren et al. [17] and Chuan et al. [18]. The key procedures of the QUEFTS model included:

(1) All data were collated and analyzed the seed yield, N, P, and K concentration of seed and straw, plant N, P, and K uptake, and the harvest index for soybean; (2) Remove outliers of data. The most necessary regulation of the QUEFTS model is that the data are not disturbed by biological or abiotic factors. Before using the QUEFTS model, it is necessary to exclude the data with a harvest index (HI) below 0.2 , because those data $(\mathrm{HI}<0.2)$ were often considered to be affected by a series of factors such as drought, diseases, and insect pests; (3) calculated the related parameters, included internal efficiencies (IE) and reciprocal internal efficiency for the three nutrients (N, P, and K). IE (Equation (1)) and reciprocal internal efficiency (RIE) (Equation (2)) using the following formula [17,21].

$$
\begin{gathered}
\mathrm{IE}=\frac{\mathrm{Y}}{\mathrm{U}} \\
\mathrm{RIE}=1000 \times \frac{\mathrm{U}}{\mathrm{Y}}
\end{gathered}
$$

where IE represents the internal efficiency (kg grain kg nutrient), RIE represents the internal efficiency, $\mathrm{Y}$ is the seed yield of the soybean $(\mathrm{kg} / \mathrm{ha})$, and $\mathrm{U}$ is $\mathrm{N}$ or $\mathrm{P}$, or $\mathrm{K}$ nutrient accumulation $(\mathrm{kg} / \mathrm{ha})$. (4) Calculated the slope of two border lines representing the maximum accumulation (a) and maximum dilution (d) of N, P, and K, respectively [12]. (5) With the parameters (a, d, and yield potential) determined, the QUEFTS model used the programming solver function to estimate the balanced nutrient uptake requirements of $\mathrm{N}, \mathrm{P}$, or $\mathrm{K}$ for the yield potential target.

\section{Results and Discussion}

\subsection{Characteristics of Yield, Nutrient Concentrations, Nutrient Harvest Index (HI)}

The grain yield of soybean ranged from $804 \mathrm{~kg} / \mathrm{ha}$ to $4484 \mathrm{~kg} / \mathrm{ha}$, with an average of $2731 \mathrm{~kg} / \mathrm{ha}$, as presented in Table 1. The maximum soybean yield in this study was lower than the maximum grain yield of $6514 \mathrm{~kg} / \mathrm{ha}$ achieved in China from 2001 to 2013, reported by Yang et al. [5]. This significant difference was most likely because of experiments being conducted in different regions, with different management practices and climate. The average grain yield in our study was higher by $928 \mathrm{~kg} / \mathrm{ha}$ and $295 \mathrm{~kg} / \mathrm{ha}$ than the average yield of $1803 \mathrm{~kg} / \mathrm{ha}$ in China and $2436 \mathrm{~kg} / \mathrm{ha}$ in the world from 2011 to 2013 [22], reflecting the improvements in management measures and soybean varieties.

Table 1. Analysis of all soybean data from 29 experiment sites in Liaoning Province of China from 2011

\begin{tabular}{|c|c|c|c|c|c|c|c|}
\hline Parameter & Unit & Mean & Min & $\begin{array}{c}25 \% \\
\text { Quartile }\end{array}$ & Median & $\begin{array}{c}75 \% \\
\text { Quartile }\end{array}$ & Max \\
\hline Grain yield & $\mathrm{kg} / \mathrm{ha}$ & 2731 & 804 & 2070 & 2793 & 3401 & 4484 \\
\hline Harvest index & $\mathrm{kg} / \mathrm{kg}$ & 0.42 & 0.14 & 0.35 & 0.43 & 0.48 & 0.60 \\
\hline $\mathrm{N}$ concentration of grain & $\mathrm{g} / \mathrm{kg}$ & 45.7 & 19.4 & 42.0 & 45.9 & 51.0 & 63.8 \\
\hline P concentration of grain & $\mathrm{g} / \mathrm{kg}$ & 5.0 & 1.4 & 3.6 & 4.9 & 6.2 & 10.3 \\
\hline $\mathrm{K}$ concentration of grain & $\mathrm{g} / \mathrm{kg}$ & 10.1 & 1.7 & 8.1 & 11.1 & 12.3 & 17.4 \\
\hline $\mathrm{N}$ concentration of straw & $\mathrm{g} / \mathrm{kg}$ & 14.1 & 4.8 & 11.6 & 14.6 & 17.0 & 29.0 \\
\hline P concentration of straw & $\mathrm{g} / \mathrm{kg}$ & 1.8 & 0.7 & 1.3 & 1.6 & 2.0 & 11.8 \\
\hline K concentration of straw & $\mathrm{g} / \mathrm{kg}$ & 6.7 & 1.7 & 4.1 & 6.5 & 8.3 & 14.8 \\
\hline Plant $\mathrm{N}$ uptake & $\mathrm{kg} / \mathrm{ha}$ & 182.6 & 58.6 & 284.7 & 151.5 & 186.8 & 213.2 \\
\hline Plant $\mathrm{P}$ uptake & $\mathrm{kg} / \mathrm{ha}$ & 21.2 & 3.5 & 61.6 & 13.9 & 18.4 & 26.6 \\
\hline plant $\mathrm{K}$ uptake & $\mathrm{kg} / \mathrm{ha}$ & 54.6 & 8.9 & 144.8 & 34.2 & 54.1 & 74.2 \\
\hline N Harvest index & $\mathrm{g} / \mathrm{g}$ & 0.69 & 0.25 & 0.91 & 0.62 & 0.71 & 0.80 \\
\hline P Harvest index & $\mathrm{g} / \mathrm{g}$ & 0.65 & 0.12 & 0.88 & 0.57 & 0.68 & 0.76 \\
\hline K Harvest index & $\mathrm{g} / \mathrm{g}$ & 0.52 & 0.14 & 0.78 & 0.43 & 0.55 & 0.64 \\
\hline
\end{tabular}
to 2013. 
Average N, P, and K concentrations in grain were $45.7 \mathrm{~g} / \mathrm{kg}, 5.0 \mathrm{~g} / \mathrm{kg}$, and $10.1 \mathrm{~g} / \mathrm{kg}$, respectively, while those in straw were $14.1 \mathrm{~g} / \mathrm{kg}, 1.8 \mathrm{~g} / \mathrm{kg}$, and $6.7 \mathrm{~g} / \mathrm{kg}$, respectively (Table 1). There were tremendously varied N, P, and K concentrations of grain $(19.4-63.8 \mathrm{~g} / \mathrm{kg}, 1.4-10.3 \mathrm{~g} / \mathrm{kg}$, and $1.7-17.4 \mathrm{~g} / \mathrm{kg}$ ) and straw $(4.8-29.0 \mathrm{~g} / \mathrm{kg}, 0.7-11.8 \mathrm{~g} / \mathrm{kg}$, and $1.7-14.8 \mathrm{~g} / \mathrm{kg})$, because of those indicators being influenced by different soil environments, fertilizers, and management conditions. Average plant $\mathrm{N}, \mathrm{P}$, and $\mathrm{K}$ uptakes were $182.6 \mathrm{~kg} / \mathrm{ha}, 21.2 \mathrm{~kg} / \mathrm{ha}$, and $54.6 \mathrm{~kg} / \mathrm{ha}$, and ranged from 58.6 to $213.2 \mathrm{~kg} / \mathrm{ha}$, from 3.5 to $26.6 \mathrm{~kg} / \mathrm{ha}$, and from 8.9 to $74.2 \mathrm{~kg} / \mathrm{ha}$, respectively (Table 1). The average plant $\mathrm{N}$ uptake in the present study was a bit higher than reported by Yang et al. [5] in China (131.5 kg/ha), and lower by $36.4 \mathrm{~kg} / \mathrm{ha}$ than Salvagiotti et al. [23] observed (219 kg/ha). The average P and $\mathrm{K}$ uptake in this study were similar to the average values of 21.8 and $47.6 \mathrm{~kg} / \mathrm{ha}$ in China reported by Yang et al. [5], respectively

Average harvest indexes (HI) of N, P, and K were $0.69,0.65$, and $0.52 \mathrm{~kg} / \mathrm{kg}$, respectively (Table 1), while approximately $69 \% \mathrm{~N}$ and $65 \% \mathrm{P}$ of the plant were stored in soybean grain, and $48 \% \mathrm{~K}$ was stored in straw. Average HIs of $\mathrm{P}$ and $\mathrm{K}$ in our study were similar to those reported by Yang et al. [5]. Overall, the results showed that the $\mathrm{HI}$ of $\mathrm{N}$ was the highest, followed by $\mathrm{P}$, and the $\mathrm{HI}$ of $\mathrm{K}$ was lowest.

\subsection{Characteristics of Internal Efficiency (IE)}

Internal efficiencies (IEs) and reciprocal internal efficiencies (RIEs) are presented in Table 2. For all soybean data, average internal efficiencies of N, P, and K were $15.3 \mathrm{~kg} / \mathrm{kg}, 149.5 \mathrm{~kg} / \mathrm{kg}$, and $60.7 \mathrm{~kg} / \mathrm{kg}$, respectively, and ranged from 8.9 to $24.1 \mathrm{~kg} / \mathrm{kg}$ for N, 42.5 to $310.5 \mathrm{~kg} / \mathrm{kg}$ for $\mathrm{P}$, and 26.1 to $243.9 \mathrm{~kg} / \mathrm{kg}$ for K (Table 2). Therefore, the corresponding average reciprocal internal efficiencies were $66.9 \mathrm{~kg} \mathrm{~N}$, $7.7 \mathrm{~kg} \mathrm{P}$, and $19.0 \mathrm{~kg} \mathrm{~K}$ to produce $1000 \mathrm{~kg}$ grain (Table 2). The proportion of N, P, and K fertilizer was 8.68:1:2.46.

Table 2. Statistical characteristic of internal efficiency (IE) and reciprocal internal efficiency of nutrient for soybean in 29 experiment sites.

\begin{tabular}{cccccccc}
\hline Parameter & Unit & Mean & Min & $\begin{array}{c}\mathbf{2 5 \%} \\
\text { Quartile }\end{array}$ & Median & $\begin{array}{c}\mathbf{7 5 \%} \\
\text { Quartile }\end{array}$ & Max \\
\hline IEN & $\mathrm{kg} / \mathrm{kg}$ & 15.3 & 8.9 & 13.9 & 15.0 & 16.8 & 24.1 \\
IEP & $\mathrm{kg} / \mathrm{kg}$ & 149.5 & 42.5 & 116.1 & 134.1 & 184.1 & 310.5 \\
IEK & $\mathrm{kg} / \mathrm{kg}$ & 60.7 & 26.1 & 44.5 & 54.4 & 66.2 & 243.9 \\
RIEN & $\mathrm{kg} / \mathrm{t}$ & 66.9 & 41.5 & 59.6 & 66.8 & 72.1 & 112.6 \\
RIEP & $\mathrm{kg} / \mathrm{t}$ & 7.7 & 3.2 & 5.4 & 7.5 & 8.6 & 23.5 \\
RIEK & $\mathrm{kg} / \mathrm{t}$ & 19.0 & 4.1 & 15.1 & 18.4 & 22.5 & 38.4 \\
\hline
\end{tabular}

\subsection{Data Screening for the QUEFTS Model}

The harvest index (HI) ranged from 0.14 to $0.60 \mathrm{~kg} / \mathrm{kg}$, with an average of 0.42 (Table 1). The results showed that the value of harvest index has a wide range, which may be caused by a series of extensive planting areas or other factors. Here, not all data are applicable to run the QUEFTS model. To ensure the accuracy of simulation results, these abnormal values need to be screened out.

Harvest index (HI) is an index applied for QUEFTS model to screen data. The standard of harvest index is different from cereal crops (rice, wheat and maize) due to the crop difference. Similar to oil rapeseed [17], the harvest index of soybean should not be less than 0.2 , because the data of $\mathrm{HI}<0.2$ is defined as the abnormal values, and those values were mostly affected by biological or nonbiological factors interference, such as diseases and drought. Thus, a black dotted line of $\mathrm{HI}=0.2$ was used to exclude abnormal values with $\mathrm{HI}<0.2$ (Figure 2). As shown in Figure 2, there were four abnormal data excluded, and normal data were used in the QUEFTS model. 


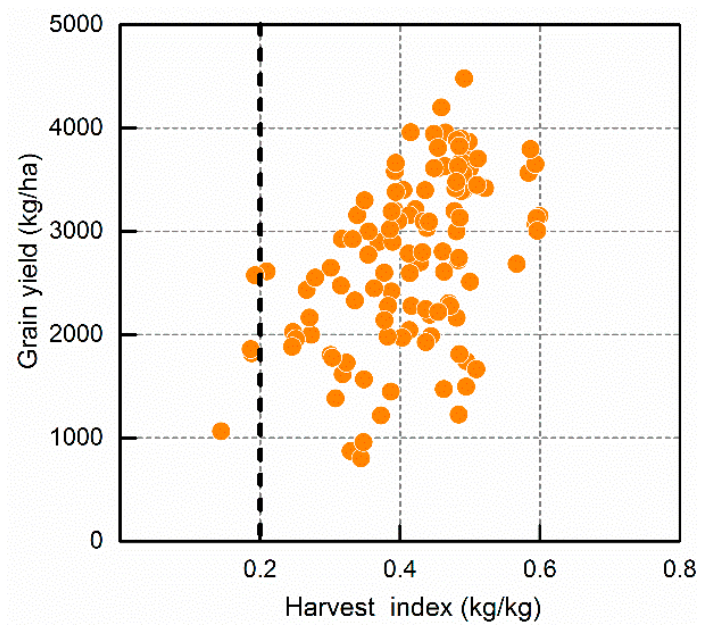

Figure 2. Relationship between grain yield and harvest index for soybean. The black line was used to exclude the value of $\mathrm{HI}<0.2$.

\subsection{The Boundary for the QUEFTS Model}

The precondition for estimating the $\mathrm{N}, \mathrm{P}$, and $\mathrm{K}$ nutrient uptake requirements for different yield potential is needed to determine the slope of the boundary line of the maximum accumulation (a) and maximum dilution (d) of N, P, and K. Based on previous studies [18], 2.5\% and $97.5 \%$ of the IE are defined as values of a and $\mathrm{d}$. To define the sensitivity of the model, the potential yield of soybean was set to $4500 \mathrm{~kg} / \mathrm{ha}$, and used the three sets of constants a and $\mathrm{d}$ to run the QUEFTS model, which calculated the upper and lower 2.5th, 5.0th, and 7.5th percentiles (Set I, Set II, Set III) of IE for soybean, presented in Figure 3. As shown in Figure 3, the simulated curves of the balanced N, P, and K uptake requirements for the three sets were not distinctive. Because Set I covered a large range of data values, the set I of a and $\mathrm{d}$ was considered as the slopes of two borderlines in the relationship between yield and nutrient uptake for soybean (Figure 3). The two slopes of two boundary lines in the QUEFTS model were $\mathrm{aN}=10.5, \mathrm{dN}=20.6, \mathrm{aP}=65.6, \mathrm{dP}=289.6, \mathrm{aK}=30.4$ and $\mathrm{dK}=162.7$ (Figure 3).
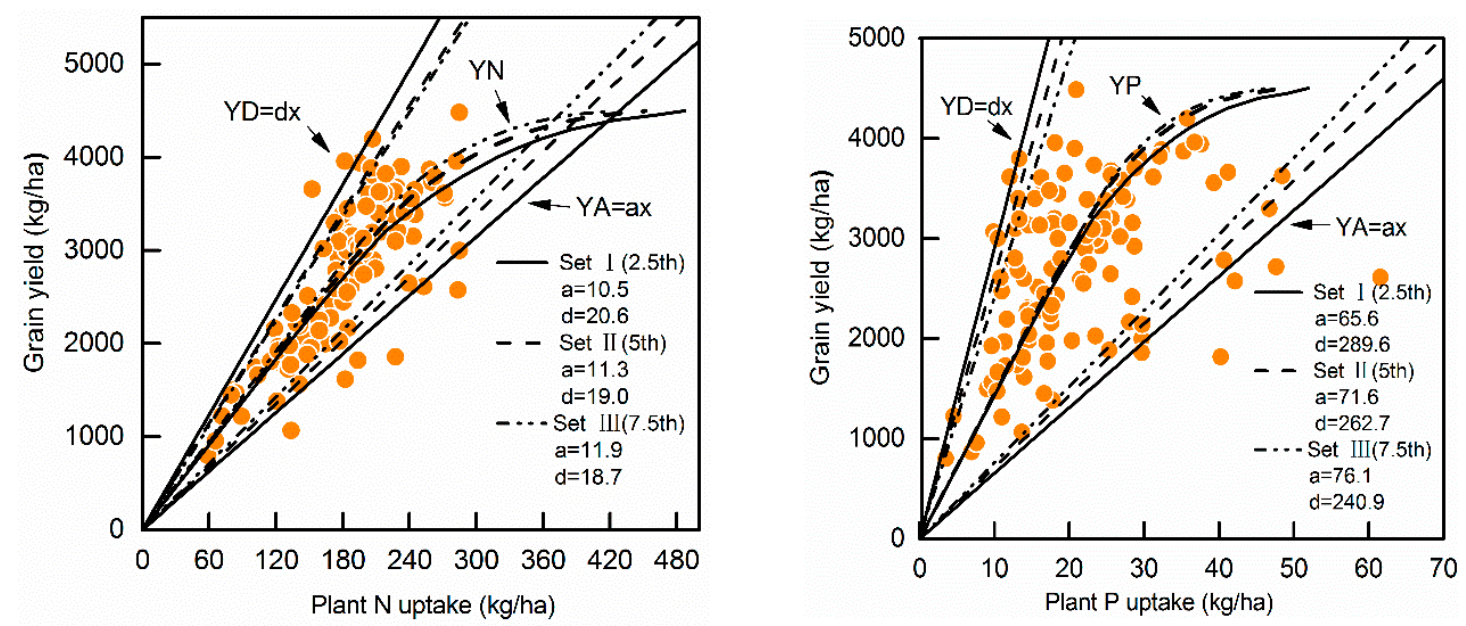

Figure 3. Cont. 


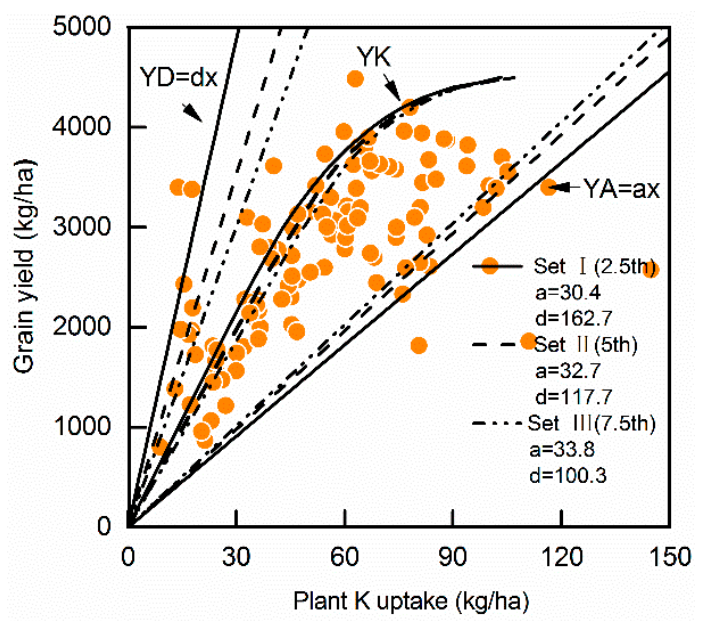

Figure 3. Balanced plant $\mathrm{N}, \mathrm{P}$, and $\mathrm{K}$ uptake requirement at three sets of a and $\mathrm{d}$ simulated by the QUEFTS model. YA and YD represent the boundary lines of the relationship between yield and uptake. YN, YP, and YK represent the balanced N, P, and K uptake curve.

\subsection{Estimating the Balanced Nutrient Uptake at Different Potential Yields for Soybean}

The QUEFTS model simulated balanced nutrient uptake requirements for each different potential yield (3000-4500 kg/ha) for soybean are shown in Figure 4. In Figure 4, the model predicted a linear increase when grain yield reached approximately $60-70 \%$ of the potential yield, and the balanced plant nutrient uptake requirements were $65.5 \mathrm{~kg} \mathrm{~N}, 7.0 \mathrm{~kg} \mathrm{P}$, and $13.9 \mathrm{~kg} \mathrm{~K}$ to produce $1000 \mathrm{~kg}$ grain. The corresponding proportion of $\mathrm{N}, \mathrm{P}$, and $\mathrm{K}$ was 9.35:1:1.8, which is similar to the optimal N:P:K ratio (7:1:2.5) for soybean, obtained by Yang et al. [5]. The corresponding IEs were $15 \mathrm{~kg} / \mathrm{kg} \mathrm{N}, 143 \mathrm{~kg} / \mathrm{kg} \mathrm{P}$, and $72 \mathrm{~kg} / \mathrm{kg} \mathrm{K}$, respectively. Additionally, when grain yield was above $70 \%$ of the potential yield, IE and RIE began to decline, which described the curve trend of the model (Figure 4). The deviation of the curve was greatly affected by the potential yield, and this trend was also observed by Yang et al. [5] for soybean. In the study, a simulated balanced nutrient uptake was also estimated to maximize the reduction in excessive fertilizer application and sustain agriculture sustainable development.
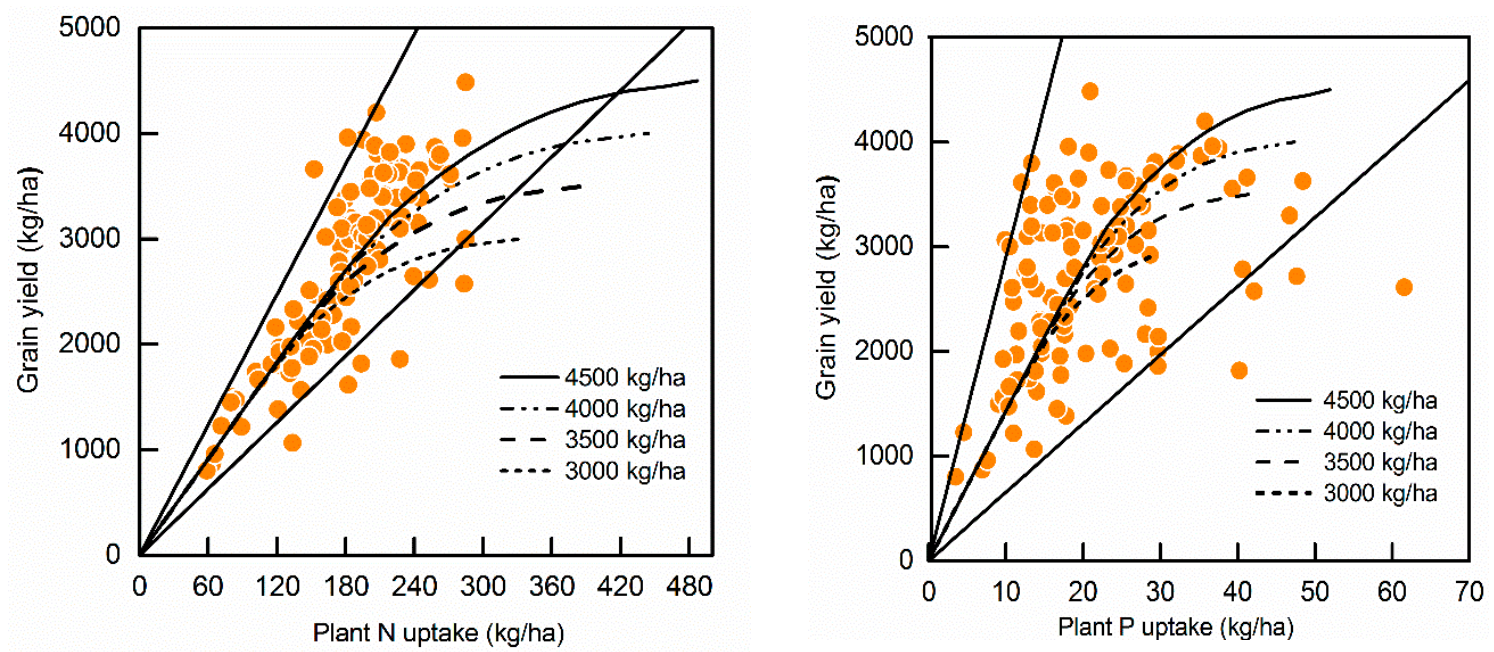

Figure 4. Cont. 


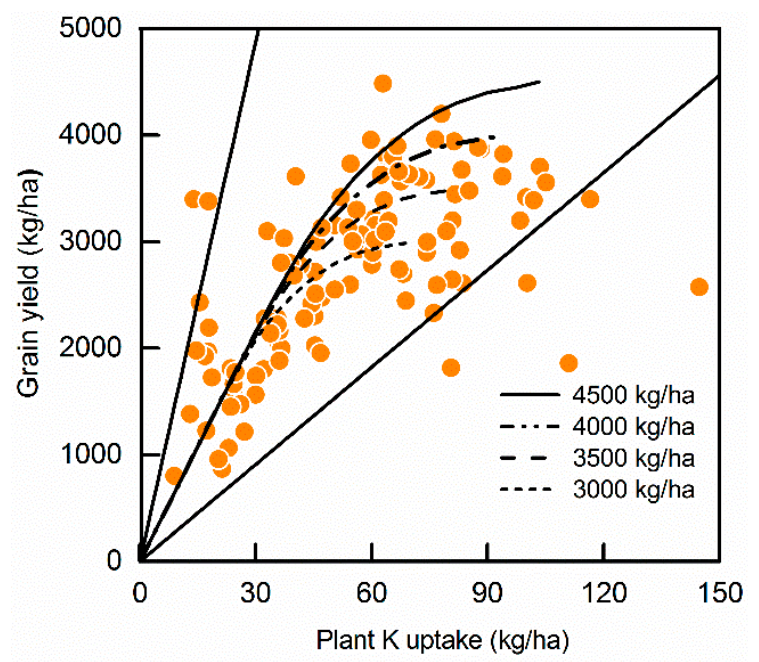

Figure 4. Application of the QUEFTS model to simulate the balanced plant N, P, and K uptake under different yield potentials ( $3000 \mathrm{~kg} / \mathrm{ha}$ to $4500 \mathrm{~kg} / \mathrm{ha}$ ) for soybean.

\section{Conclusions}

A dataset from 29 experimental sites was used to evaluate the balanced plant nutrient requirements for yield potential in Liaoning province, China. The grain yield of soybean ranged from 804 to $4484 \mathrm{~kg} / \mathrm{ha}$, and average $\mathrm{N}, \mathrm{P}$, and $\mathrm{K}$ concentrations in grain were $45.7,5.0$, and $10.1 \mathrm{~g} / \mathrm{kg}$, respectively, while those in straw were $14.1,1.8$, and $6.7 \mathrm{~g} / \mathrm{kg}$, respectively. Average N, $\mathrm{P}$, and $\mathrm{K}$ uptake were 182.6, 21.2, and $54.6 \mathrm{~kg} / \mathrm{ha}$, respectively. Calibration of the QUEFTS model for soybean required estimating the slopes of two boundary lines describing the maximum accumulation (a) and dilution (d) of N, P, and K, and proposing $\mathrm{N}=10.5, \mathrm{dN}=20.6, \mathrm{aP}=65.6, \mathrm{dP}=289.6, \mathrm{aK}=30.4$, and $\mathrm{dK}=162.7$ as the standard coefficients in QUEFTS. Based on the parameters settings, the balanced nutrient requirements calculated by QUEFTS model increased linearly until the yield reached about $60-70 \%$ of the yield potential; $65.5 \mathrm{~kg} \mathrm{~N}, 7.0 \mathrm{~kg} \mathrm{P}$, and $13.9 \mathrm{~kg} \mathrm{~K}$ were required to produce $1000 \mathrm{~kg}$ grain. To conclude, it confirmed that the QUEFTS model could be used to calibrate the estimated balanced nutrient uptake and help to prevent nutrient losses, and these values contributed to improved fertilizer recommendations to optimize nutrient management practices.

Author Contributions: W.J. wrote the paper, W.J. and X.L. designed the study idea and applied the model to calculated, X.L. collected and arranged the all database, W.J. and X.W. analyzed and discussed. W.J., X.L., X.W. and Y.Y. revised the manuscript.

Funding: The present study was supported by the Specialized Research Fund for the Doctoral Program of Yan'an University (YDBK2018-51) and the National Key Research and Development Program of China (Grant number 2016YFD0200105).

Conflicts of Interest: The authors declare no conflict of interest.

\section{References}

1. Wang, X.K.; Fan, J.L.; Xing, Y.Y.; Xu, G.C.; Wang, H.D.; Deng, J.; Wang, Y.F.; Zhang, F.C.; Li, P.; Li, Z.B. The effects of mulch and nitrogen fertilizer on the soil environment of crop plants. Adv. Agron. 2019, 153, 121-173.

2. Godfray, H.C.J.; Beddington, J.R.; Crute, I.R.; Lawrence, H.; David, L.; Muir, J.F.; Jules, P.; Sherman, R.; Thomas, S.M.; Camilla, T. Food security: The challenge of feeding 9 billion people. Science 2010, 327, 812-818. [CrossRef]

3. Li, X.; Xu, Z.; Guo, C.; Ren, T.; Cong, R.; Lu, J. Grain yield and nitrogen use efficiency of various modern rice cultivars grown at different nitrogen levels. J. Plant Nutr. 2017, 40, 1125-1132. [CrossRef]

4. Liu, X.; Jin, J.; Wang, G.; Herbert, S.J. Soybean yield physiology and development of high-yielding practices in Northeast China. Field Crops Res. 2008, 105, 157-171. [CrossRef] 
5. Yang, F.; Xu, X.; Wang, W.; Ma, J.; Wei, D.; He, P.; Pampolino, M.F.; Johnston, A.M. Estimating nutrient uptake requirements for soybean using QUEFTS model in China. PLoS ONE 2017, 12, e0177509. [CrossRef]

6. Ball, R.A.; Purcell, L.C.; Vories, E.D. Optimizing soybean plant population for a short-season production system in the southern USA. Crop Sci. 2000, 40, 757-764. [CrossRef]

7. Mueller, N.D.; Gerber, J.S.; Matt, J.; Ray, D.K.; Navin, R.; Foley, J.A. Closing yield gaps through nutrient and water management. Nature 2013, 494, 390. [CrossRef]

8. Xu, X.; He, P.; Yang, F.; Ma, J.; Pampolino, M.F.; Johnston, A.M.; Zhou, W. Methodology of fertilizer recommendation based on yield response and agronomic efficiency for rice in China. Field Crops Res. 2017, 206, 33-42. [CrossRef]

9. Guo, J.H.; Liu, X.J.; Zhang, Y.; Shen, J.L.; Han, W.X.; Zhang, W.F.; Christie, P.; Goulding, K.W.T.; Vitousek, P.M.; Zhang, F.S. Significant acidification in major Chinese croplands. Science 2010, 327, 1008-1010. [CrossRef]

10. Wang, X.K.; Li, Z.B.; Xing, Y.Y. Effects of mulching and nitrogen on soil temperature, water content, nitrate-N content and maize yield in the Loess Plateau of China. Agric. Water Manag. 2015, 161, 53-64.

11. Zhang, B.; Feng, G.; Kong, X.; Lal, R.; Ying, O.; Adeli, A.; Jenkins, J.N. Simulating yield potential by irrigation and yield gap of rainfed soybean using APEX model in a humid region. Agric. Water Manag. 2016, 177, 440-453. [CrossRef]

12. Xu, X.; Xie, J.; Hou, Y.; He, P.; Pampolino, M.F.; Zhao, S.; Qiu, S.; Johnston, A.M.; Zhou, W. Estimating nutrient uptake requirements for rice in China. Field Crops Res. 2015, 180, 37-45. [CrossRef]

13. Janssen, B.H.; Guiking, F.C.T.; Der Eijk, D.V.; Smaling, E.M.A.; Wolf, J.; Van Reuler, H.A. System for quantitative evaluation of the fertility of tropical soils (QUEFTS). Geoderma 1990, 46, 299-318. [CrossRef]

14. Smaling, E.M.A.; Janssen, B.H. Calibrating of QUEFTS, a model predicting nutrient uptake and yields from chemical soil fertilty indices. Geoderma 1993, 59, 21-44. [CrossRef]

15. Witt, C.; Dobermann, A.; Abdulrachman, S.; Gines, H.C.; Guanghuo, W.; Nagarajan, R.; Satawatananont, S.; Son, T.T.; Tan, P.S.; Simbahan, G.C.; et al. Internal nutrient efficiencies of irrigated lowland rice in tropical and subtropical Asia. Field Crops Res. 1999, 63, 113-138. [CrossRef]

16. Liu, M.Q.; Yu, Z.R.; Liu, Y.H.; Konijn, N.T. Fertilizer requirements for wheat and maize in China: The QUEFTS approach. Nutr. Cycl. Agroecosyst. 2006, 74, 245-258. [CrossRef]

17. Ren, T.; Zou, J.; Wang, Y.; Li, X.K.; Cong, R.H.; Lu, J.W. Estimating nutrient requirements for winter oilseed rape based on QUEFTS analysis. J. Agric. Sci. 2016, 154, 425-437. [CrossRef]

18. Chuan, L.; He, P.; Jin, J.; Li, S.; Grant, C.; Xu, X.; Qiu, S.; Zhao, S.; Zhou, W. Estimating nutrient uptake requirements for wheat in China. Field Crops Res. 2013, 146, 96-104. [CrossRef]

19. Pathak, H.; Aggarwal, P.K.; Roetter, R.; Kalra, N.; Bandyopadhaya, S.K.; Prasad, S.; Van, K.H. Modelling the quantitative evaluation of soil nutrient supplies, nutrient use effi ciency, and fertilizer requirements of wheat in India. Nutr. Cycl. Agroecosyst. 2003, 65, 105-113. [CrossRef]

20. Li, S.T.; Jin, J.Y. Characteristics of nutrient input/output and nutrient balance in different regions of China. Sci. Agric. Sin. 2011, 44, 4207-4229. (In Chinese)

21. Klikocka, H.; Cybulska, M.; Nowak, A. Efficiency of fertilization and utilization of nitrogen and sulphur by the spring wheat. Pol. J. Environ. Stud. 2017, 26, 2029-2036. [CrossRef]

22. FAOSTAT. Food and Agriculture Organization of the United Nations. Agricultural Production Data. Available online: http://www.fao.org/faostat/en/.

23. Salvagiotti, F.; Cassman, K.G.; Specht, J.E.; Walters, D.T.; Weiss, A.; Dobermann, A. Nitrogen uptake fixation and response to fertilizer $\mathrm{N}$ in soybeans: A review. Field Crops Res. 2008, 108, 1-13. [CrossRef]

(C) 2019 by the authors. Licensee MDPI, Basel, Switzerland. This article is an open access article distributed under the terms and conditions of the Creative Commons Attribution (CC BY) license (http://creativecommons.org/licenses/by/4.0/). 